\title{
Pemaknaan Maskulinitas pada Majalah Cosmopolitan Indonesia
}

\author{
Sumekar Tanjung \\ Dosen Program Studi Ilmu Komunikasi \\ Universitas Islam Indonesia (UII), Yogyakarta
}

\begin{abstract}
Nowadays, the position of men and women has no difference. Men and women are treated equally as a commodity. The phenomenon of hegemonic masculinity have been well understood, despite the fact that media especially magazine, is a medium for the contest between masculinity and femininity. This study focuses on how masculinity of man is represented in Cosmopolitan Indonesia Magazine (August, September, October and December 2011 editions).
\end{abstract}

Keywords: semiotic, woman magazine, masculinity

\begin{abstract}
Abstrak
Saat ini, posisi laki-laki dan perempuan tak lagi berbeda. Laki-laki maupun perempuan diperlakukan sama sebagai komoditas. Fenomena hegemoni maskulinitas telah lama dipahami, terlepas dari fakta bahwa media terutama majalah, adalah ajang bagi kontes antara maskulinitas dan femininitas. Kajian ini akan berfokus pada representasi maskulinitas laki-laki di majalah Cosmopolitan Indonesia (edisi bulan Agustus, September, Oktober, dan Desember 2011).
\end{abstract}

Kata Kunci: semiotika, majalah perempuan, maskulinitas

\section{Pendahuluan}

Masyarakat mencatat bahwa secara kultural laki-laki harus menonjolkan sisi maskulin. Sedangkan perempuan juga harus menonjolkan sisi feminin. Istilah maskulin sendiri sebenarnya berasal dari bahasa Inggris "muscle" atau otot, yaitu sifat-sifat yang hanya mendasarkan pada kekuatan otot atau fisik (Smiler, 2004). Meski tidak ada definisi konkret, maskulin atau maskulinitas lebih dipahami sebagai konsep gender tentang perilaku yang dibangun secara sosial dan berkaitan dengan kelelakian. Sesungguhnya tidak ada model tunggal dalam maskulinitas. Ini disebabkan karena model maskulinitas diungkapkan secara berbeda dalam suatu konteks budaya dan waktu tertentu.

Meski maskulinitas dan femininitas adalah konsep nilai yang kontradiktif, tapi keduanya dapat dipertukarkan. Artinya, femininitas tidak mesti hanya dimiliki perempuan dan maskulinitas tidak hanya dimiliki lakilaki. Sebab pada praktiknya, laki-laki mengandalkan sikap feminin. Misal, dalam pekerjaan mereka tidak serta merta hanya mengandalkan keberanian, tapi 
juga harus berkomunikasi secara lembut, sopan, dan tidak semena-mena. Kemudian pada pihak perempuan, masyarakat memandang mereka sebagai sosok lemah lembut, pasif, dan pemalu. Stereotipe ini tidak selamanya berlaku secara murni dalam masyarakat. Dalam praktiknya, perempuan juga mengandalkan kekuatan saat bekerja. Mereka juga menggunakan ketegasan serta keberanian saat memutuskan suatu hal dalam menghadapi situasi tertentu.

Berlawanan dengan hal di atas, masyarakat patrilineal Indonesia menilai bahwa perempuan tidak memiliki karakter maskulin. Seharusnya perempuan hanya memiliki karakter feminin saja. Sedangkan bagi perempuan yang tidak feminin, dinyatakan melanggar dan memperoleh sanksi. Demikian pula karakter maskulin yang hanya dimiliki laki-laki. Jika laki-laki tidak mengadopsi dan memiliki karakter maskulin, lingkungan sosial akan menyebutnya sebagai banci, klemar-klemer, dan kemayu.

Pandangan dominan tentang citra ideal perempuan dan laki-laki, sebenarnya telah diimbangi oleh penggambaran alternatif dalam sejumlah teks media dan produk budaya populer. Misalnya, perempuan sudah digambarkan menjadi pemimpin, berambut sangat pendek, dan memakai celana panjang. Sementara lakilaki mengasuh anak, memasak, berambut panjang, dan berprofesi sebagai pelatih tari. Ini berarti, stereotipe feminin dan maskulin telah terbantahkan. Meski demikian, media semakin kuat dalam memengaruhi masyarakat. Segala yang dibeberkan oleh media dianggap sebagai sesuatu yang normal, wajar, benar, dan standar.

Sebagai wilayah yang dijadikan perebutan tanda dan makna, media menjunjung tinggi maskulinitas hegemonik dalam masyarakat. Maskulinitas hegemonik dapat dipahami sebagai pembenaran dan pengesahan atas dominasi kuasa laki-laki dalam kehidupan sosial. Beroperasinya maskulinitas hegemonik dapat dibaca pada salah satu majalah franchise populer di Indonesia yakni Cosmopolitan. Di Indonesia, Majalah Cosmopolitan Indonesia menduduki peringkat ketiga setelah Femina dan Tempo, sebagai majalah franchise asing pertama yang memperoleh kue iklan terbanyak tahun 2010 (Laporan Tahunan AJI, 2011: 110).

Sebagai majalah perempuan, tentu saja Cosmopolitan Indonesia memuat segala informasi tentang perempuan. Meski demikian, sasaran Cosmopolitan Indonesia tidak serta merta hanya untuk perempuan. Dalam beberapa rubrik seperti Entertainment, Man Manual, Informer, Shopping, Love and Lust, You, You, You, Only in Cosmo, Your Work Zone, Fashion and Beauty, Health Check, Weekend, dan In Every Issue, isinya secara khusus ditujukan kepada laki-laki. Cosmopolitan Indonesia juga menyajikan tulisan yang mencirikan stereotipe laki- 
laki pada diri perempuan, seperti artikel tentang kesuksesan perempuan dalam karir. Dengan demikian, citra perempuan yang serba feminin tidak selalu mendominasi Cosmopolitan Indonesia.

Dalam kaitannya dengan maskulinitas hegemonik, media memberikan penggambaran melalui isi, pemberitaan, dan kebijakan yang banyak dijalankan oleh maskulinitas. Pada maskulinitas yang hegemonik sebenarnya tidak hanya perempuan yang tersubordinasi, laki-laki yang berada dalam situasi dan kondisi yang dianggap minoritas juga turut tersubordinasi. Penampilan fisik yang dinilai mengundang ketertarikan pembaca seperti perut six packs, berotot, kekar, sehat, modern, berkeringat, dan trendy, dikelola dalam beberapa rubrik. Sedangkan laki-laki yang berbadan biasa, wajah tidak menarik, ketinggalan jaman, dan norak pun diremehkan. Ini menunjukkan betapa konsep mengenai maskulinitas berubah-ubah.

Berawal dari latar belakang di atas, penelitian ini ingin menjawab bagaimana makna maskulinitas pada laki-laki yang dideskripsikan majalah Cosmopolitan Indonesia edisi Agustus, September, Oktober dan Desember 2011.

\section{Metode Penelitian}

Penelitian ini merupakan riset interpretatif dengan pendekatan kualitatif dan berparadigma kritis. Penelitian interpretatif merupakan studi tentang pendekatan subjektif yang sering disebut juga dengan humanistik. Dengan pendekatan semacam ini dianggap tidak akan ada replikasi yang sama persis, karena realitas yang diteliti (serta hubungan antara peneliti dan subjek yang diteliti) selalu terikat oleh konteks ruang dan waktu yang berbeda pula. Jelasnya, dengan perbedaan ruang dan waktu, maka akan berbeda pula pemaknaan dari masing-masing peneliti.

Semiotika dalam hal ini merupakan metode analisis yang tepat untuk memperoleh pemahaman tentang makna tersembunyi dalam foto. Untuk dapat memaknai pembacaan tentang maskulinitas dalam Majalah Cosmopolitan Indonesia, maka digunakanlah prinsip analisis semiotika yang mampu menjelaskan berbagai tanda teks verbal dan teks visual dalam artikel. Pada teks verbal, peneliti mengacu pada Barthes (2000) mengenai denotasi dan konotasi. Peneliti dalam mengintepretasikan makna teks verbal dengan cara memilah teks yang representatif. Kemudian diartikan dengan maksud yang terkandung di dalam teks tersebut, sesuai dengan apa yang tertulis dalam tahap denotasi dan konotasi.

Untuk mengetahui maskulinitas yang ditampilkan Cosmopolitan Indonesia, maka peneliti melakukan penelitian terhadap teks verbal dan teks visual. Teks verbal yang diteliti adalah teks (unsur kata dan kalimat) yang mewakili 
atau merepresentasikan maskulinitas secara sosial budaya. Teks adalah pesanpesan tertulis, yaitu produk bahasa dalam bentuk tulisan. Sedangkan teks visual adalah "teks", yang di dalamnya melibatkan unsur-unsur visual. Di sini, teks visual yang dimaksud adalah foto dalam artikel.

Penentuan objek penelitian dilakukan secara purposif dengan memilah objek yang dianggap merepresentasikan konsep maskulinitas dalam majalah Cosmopolitan Indonesia. Seluruh anggota populasi artikel dalam Cosmopolitan Indonesia diseleksi dan dipertimbangkan berdasarkan konsep maskulinitas. Objek yang dipilih yakni delapan artikel dalam empat edisi (Agustus, September, Oktober dan Desember 2011) yang terpilih dari enam edisi (Agustus 2011 hingga Januari 2012) Cosmopolitan Indonesia. Pemilihan tersebut didasari oleh faktor kebaruan majalah dan kedekatan waktu penelitian.

Pada rentang Agustus 2011 hingga Januari 2012, terdapat 10 rubrik tetap dalam tiap edisi. Umumnya, Cosmopolitan Indonesia menggunakan format penulisan artikel sebagai penyampaian. Adapun ragam bentuk artikel yang digunakan Cosmopolitan Indonesia yakni artikel how to, artikel wawancara, artikel profil dan artikel informasi.

Pada enam edisi tersebut ditemukan sebanyak 313 artikel. Dari ratusan artikel yang ada, delapan artikel dipilih untuk diteliti. Pemilihan artikel tersebut didasarkan pada faktor keterwakilan konsep maskulinitas yang paling sering muncul. Pemilihan ini disimpulkan setelah dilakukan pembacaan secara menyeluruh terhadap Cosmopolitan Indonesia edisi Agustus 2011 hingga Januari 2012. Tentu saja, dalam penentuan luas objek penelitian, prinsip kejenuhan data menjadi suatu pertimbangan (Muhadjir, 200o).

Pada teks visual atau foto (foto pendamping artikel), penulis menggunakan enam tahap prosedur pemilihan konotasi dari Barthes dalam The Photographic Message (2000). Prosedur-prosedur tersebut terbagi dalam dua bagian besar, pertama, konotasi yang diproduksi melalui modifikasi atau intervensi langsung terhadap realita itu sendiri. Ini terdiri dari tiga hal, yakni trick effect, pose, dan objek. Kedua, konotasi yang diproduksi melalui wilayah estetis foto, yakni photogenia, aestethism, dan sintaksis. Keenam prosedur ini digunakan sebagai prinsip meneliti. Keenam prosedur tidak digunakan secara dominan, melainkan hanya salah satu di antaranya. Ini disebabkan karena kehadiran tanda utama dianggap sebagai pendukung atas tanda lain. Peneliti kemudian mengaitkan teks dengan konteks sosial dalam masyarakat. Tahap ini disebut sebagai mitos yang digunakan sebagai uji validitas data. 
Maskulinitas dalam Konsep Biologis dan Konstruksi Sosial

Istilah maskulin sebenarnya berasal dari bahasa Inggris "muscle" atau otot, yaitu sifat-sifat yang hanya mendasarkan pada kekuatan otot atau fisik (Smiler, 2004). Meski tidak ada definisi konkret, maskulin atau maskulinitas lebih dipahami sebagai konsep gender tentang perilaku yang dibangun secara sosial dan terkait dengan kelelakian. Sesungguhnya tidak ada model tunggal dalam maskulinitas. Ini disebabkan karena model maskulinitas diungkapkan secara berbeda dalam suatu konteks budaya dan waktu tertentu.

Connell berpendapat bahwa maskulinitas tidak akan ada jika tidak dipersandingkan dengan femininitas. Terminologi maskulinitas sebenarnya tidak memiliki makna apapun. Hanya saja, dalam struktur sosial, perilaku masyarakat mencerminkan demikian. Connell kemudian melakukan empat klasifikasi atas pemahaman maskulinitas dalam perspektif ilmiah. Pertama, dari pandangan positivis, maskulinitas berupaya menggambarkan "what men actually are" dengan menghubungkan antara hal biologis atau pengelompokan sosial. Kedua, dari pendekatan normatif, masyarakat memiliki konsep sendiri terhadap "what men ought to be". Ketiga, perspektif esensialis yang memiliki pemahaman bahwa maskulinitas diperoleh dari kepribadian masing-masing atau hormon yang dibawa. Keempat, dalam pendekatan semiotika, perbedaan maskulinitas dan femininitas menjadikannya sebagai ruang simbolik. Di sini, maskulinitas didefinisikan sebagai non-femininitas. Penanda maskulinitas (memiliki phallus) dibedakan dengan femininitas (tidak memiliki phallus). Ini digunakan untuk memeriksa hubungan kekuasaan secara simbolis antara laki-laki dan perempuan (Connell, 1995: 68-70).

Maskulinitas pada diri laki-laki telah diatur semenjak kelahirannya saat bayi. Setelah dilahirkan, bayi segera diberikan batasan-batasan sesuai jenis kelamin, memperoleh hak tertentu, dan orangtua menggantungkan harapan kepadanya hingga dewasa nanti. Banyak orang mengatakan, "ini anak laki-laki" atau "ini anak perempuan" ketika bayi lahir. Pembedaan ini membuat tiap orang mengasumsikan bahwa faktor biologis berpengaruh pada perilaku gender.

Menurut Badinter, bayi laki-laki atau perempuan memulai kehidupannya di dalam tubuh perempuan. Bayi laki-laki nantinya perlahan meninggalkan femininitas mereka dari sang ibu ke diri yang maskulin. Sedangkan bayi perempuan menurunkan sikap femininitas mereka layaknya seorang ibu. Tidak seperti femininitas yang diwariskan begitu saja dari ibu, tapi maskulinitas harus diciptakan oleh seorang anak lakilaki. Dalam perspektif yang ditulisnya, Badinter kemudian memberikan 
kesimpulan bahwa tipe laki-laki dewasa yang tidak menurunkan nilai-nilai keibuan disebut "tough guy". Sedangkan mereka yang menurunkan perilaku dan nilai-nilai keibuan adalah "soft man" (Badinter, 1995: 43).

Dalam pengamatannya, muncul perbedaan pemahaman maskulinitas yang telah ditemukan sebelumnya. Dulu, maskulinitas dilihat sebagai suatu hal yang timbul secara alamiah dari segi biologis. Namun, kini laki-laki dituntut untuk membuktikan maskulinitasnya, hingga menjadi suatu kewajiban untuk dilakukan. Meski tidak ada aturan tertulis, namun semua masyarakat di dunia seolah memiliki standar yang sama tentang maskulinitas.

Laki-laki diharuskan memiliki aturan yang tidak tertulis untuk memperkokoh maskulinitas. Pertama, "no sissy stuff" atau laki-laki tidak boleh memiliki sikap dan sifat keperempuanan. Kedua, "be a big wheel". Seorang laki-laki harus memiliki kekuatan, kekuasaan dan status. Ketiga, "be a sturdy oak". Laki-laki harus memiliki jiwa yang kokoh dan keras. Terakhir, "give 'em hell", laki-laki harus bertanggung jawab, agresif, dan mampu mengambil risiko (Beynon, 2002). Meski empat aturan tersebut muncul puluhan tahun sebelumnya, namun beberapa di antaranya masih berlaku saat ini.

\section{Kuasa Maskulinitas Hegemonik}

Kini semakin sulit untuk menarik kesimpulan secara jelas tentang masalah maskulinitas dalam masyarakat. Konsep maskulinitas dilanggengkan secara turuntemurun dalam kondisi budaya setempat. Seperti feminin, pencitraan maskulin diaplikasikan dalam segala hal, simbol, benda, dan warna. Apa yang dianggap maskulin di suatu tempat, dapat dianggap feminin dalam budaya lain. Ini tergantung pada konteks sosial budaya setempat.

Upaya melanggengkan itu sendiri dapat dikatakan sebagai wujud maskulinitas turun-temurun, yang berusaha mempertahankan konsep kelelakian sepanjang masa. Konteks "melanggengkan" atau “mempertahankan" ini tercakup dalam satu hal, yakni kekuasaan. Pencapaian kuasa atas kontrol maskulin terhadap perempuan, diperoleh melalui pengaturan kehidupan pribadi dan proses budaya. Inilah yang kemudian dikatakan sebagai maskulinitas hegemonik.

Dominasi maskulinitas hegemonik di sini memiliki tiga efek terhadap lakilaki. Pertama, dijelaskan oleh Connell sebagai complicity atau proses keterlibatan laki-laki yang tidak memenuhi standar hegemonik (1995: 79). Alih-alih tanpa menempatkan diri pada garis hegemonik, laki-laki yang berada pada posisi ini mengambil keuntungan sebagai strategi untuk memperkuat dan mendominasi. Efek kedua adalah 
subordinasi, kemampuan maskulinitas hegemonik untuk mendorong keluar dan menekan kelompok laki-laki penentang hegemonik. Misalnya, penolakan laki-laki heteroseksual terhadap homoseksual. Ketiga, efek marjinalisasi yang cenderung terjadi pada kaum kulit hitam. Perspektif majalah pada umumnya mendukung mereka para kaum kulit putih yang lebih teratur dan rapi daripada kulit hitam.

Dalam banyak hal, identitas maskulinitas hegemonik saat ini selaras dengan konsep maskulinitas tradisional. Connell mencatat bahwa posisi hegemonik selalu unik dalam setiap pola hubungannya dengan gender di mana berada. Ia tidak langsung menetap pada diri seseorang, melainkan diperebutkan. Akibatnya, relasi gender masyarakat dapat dikatakan sebagai arena perjuangan. Pemain yang dominan memperoleh eksistensi yang nyata (Connell, 1995: 7677). Teori ini relevan dengan penelitian yang dilakukan terhadap majalah Cosmopolitan Indonesia. Sebagai representasi gaya hidup, majalah dapat dilihat sebagai ruang hegemoni atas perilaku, minat, dan karakter. Kesemuanya berada dalam lingkaran maskulinitas.

$\begin{array}{rrr}\text { Meski } & \text { demikian, } & \text { proses } \\ \text { pembentukan } & \text { dan } & \text { penyebaran }\end{array}$ maskulinitas tidak serta merta menjadi milik budaya, tapi juga media. Media merupakan agen sosialisasi sekunder yang dampak penyebarannya paling luas.
Meskipun dampak yang diberikan media tidak secara langsung terjadi, namun cukup signifikan dalam memengaruhi seseorang. Media dapat membentuk pencitraan tertentu dari suatu peristiwa atau suatu kelompok dan dipahami sebagai kebenaran umum dalam masyarakat. Pencitraan yang sudah begitu melekat dalam masyarakat, berkembang menjadi stereotipe yang kemudian diteruskan intra dan intergenerasi. Salah satu stereotipe yang berkembang dalam masyarakat Indonesia dan dunia adalah mengenai kaum homoseksual yang dianggap menyimpang dari norma.

\section{Maskulinitas dalam Majalah, Dahulu dan Sekarang}

Dalam konteks tradisional, majalah identik dengan suatu media yang dicetak dan dikemas secara khusus yang biasanya tersegmentasi secara jelas. Setidaknya, majalah memiliki cakupan berupa tiga aspek. Pertama, majalah lebih beragam penggunaannya. Kedua, majalah lebih personal penggunaannya. Ketiga, tema majalah lebih bersifat mendalam, memungkinkan pembacanya untuk menganalisis kembali pesan yang disampaikan.

Awal perkembangannya di Amerika, majalah umumnya hanya dikonsumsi oleh kaum laki-laki saja. Sebab masa itu tingkat melek hurufnya lebih tinggi daripada kaum perempuan. Karena itu, pemberitaannya pun 
berorientasi pada kepentingan kaum lakilaki pada masa itu. Abad 19 mulai muncul majalah dengan target konsumen perempuan dan pemberitaannya seputar aktivitas di waktu senggang dan keterampilan rumah tangga. Orientasi pasar menjadi semakin jelas. Perkembangan teknologi selanjutnya membuat terciptanya segmentasi dan spesialisasi isi majalah hingga mampu membidik konsumen. Kebanyakan majalah bertahan dengan rumus baku dan isi medianya didikte oleh pengiklan, dengan cara menekankan pola isi seperti apa yang akan membantu pemasaran produk-produk mereka. Atau bisa juga berdasarkan gagasan-gagasan para pemilik media tentang apa yang mereka anggap dapat menaikkan tiras.

Meski tidak begitu cermat memperhatikan perkembangan majalah yang tumbuh sejak 1970-an, namun dari pengalaman wacana yang diperoleh penyusun, menyiratkan bahwa di sana ada idealisme laki-laki dan perempuan khususnya untuk mengembangkan diri sebagai individu. Mandiri, berwawasan luas, dan tidak didominasi kekuasaan lakilaki. Majalah-majalah ini juga mengonsepsikan citra perempuan ideal, tak terbelenggu rutinitas rumah tangga, tapi juga responsif.

Majalah kecantikan dan fashion seperti Cosmopolitan, Vogue, Esquire, selama ini memiliki citra kurang baik oleh masyarakat. Dari tuduhan elitisme, mempromosikan standar kecantikan yang tidak masuk akal, kedangkalan isi, sampai rasisme. Pangsa pasarnya yang terbatas pada masyarakat kelas atas, cenderung membuat majalah semacamnya bereaksi terhadap kritik seperti ini dengan diam. Isinya yang seksis secara tidak langsung menempatkan perempuan sebagai objek seks dengan memasang mereka sebagai sekadar clothes hangers dan bukan sebagai diri sendiri (Johani, 2000: 99). Majalah-majalah ini menjual apa yang tidak dimiliki oleh pembacanya dan apa yang ingin mereka miliki. Majalah semacam ini adalah menjual impian. Mereka mengisi tiap halaman dengan fantasi-fantasi yang tidak ada hubungannya dengan kenyataan. Kebahagiaan perempuan yang semula telah direkonstruksi oleh budaya, semakin diperkokoh melalui pemahaman bertindak dari majalah. Keahlian perempuan diarahkan melalui ketekunan menggunakan produk-produk feminin dan mengikuti fashion tanpa menghiraukan dorongan yang monoton dari pembacaan media ini.

Sesuai dengan pemikiran Billman, "Men are now maintaining their masculine status through the repetition of building and maintaining this masculine body image" (dalam Journal Universitas, Vol. 2, Fall 2, 2006: 4). Fenomena ini terjadi dan tercermin dalam majalah, seperti Cosmopolitan, Men's Health, Esquire, dan For Him (berada di bawah naungan MRA Grup). Majalah tersebut selalu menampilkan laki-laki yang "ideal" 
dan tidak pernah menampilkan laki-laki gemuk.

Mark Simpson memberikan julukan metroseksual dalam artikelnya di suratkabar Independent pada 1994. Artikel tersebut ditulis untuk mendeskripsikan suatu jenis baru laki-laki muda yang eksotis dalam iklan pakaian dalam Calvin Klein yang dikenakan oleh seorang model. Kategori laki-laki baru ini memiliki karakter sendiri, yakni sifat narsistik yang tinggi, sehingga dia selalu memperhatikan penampilan (dandy). Menurut Simpson, gejala yang disebut sebagai laki-laki baru ini hanyalah konstruksi dari pengiklan majalah glossy (istilah yang selalu digunakan Simpson untuk menunjuk majalah gaya hidup), yang menjual produk mahal dengan mengeksploitasi ketidakamanan laki-laki moderen (Wibowo, 2006: 189-190).

Konsep maskulinitas dan femininitas membawa problematika tentang tubuh. Gaya hidup yang telah menjelma menjadi komoditas, menganggap konsep pendisiplinan dan pembentukan tubuh sebagai suatu standar. Kriteria tubuh ideal pun melanda laki-laki. Di negara-negara maju, banyak bermunculan istilah "new man", yang hampir mirip dengan "laki-laki macho". New man menjadi potret beralihnya lakilaki sebagai tontonan atau objek.

$\begin{array}{lcr}\text { Melihat hal } & \text { tersebut, laki-laki } \\ \text { seolah memiliki } & \text { kecemasan } & \text { pada } \\ \text { tubuhnya sendiri. } & \text { Mereka } & \text { selalu }\end{array}$

memproyeksikan tubuhnya pada konsep ideal milik media. Untuk mendukung gaya hidup ini banyak media mengangkatnya menjadi berita, bahkan kolom khusus. Banyak pula majalah perempuan atau majalah for men memajang tubuh mereka dalam ruang tertentu. Contohnya, seorang laki-laki hanya menggunakan pakaian dalam. Penggunaan butter memberikan efek mengkilap pada tubuh, serta otot model yang dapat memperkuat sisi maskulin. Menurut Gauntlet (2002: 191) menyebut model laki-laki seperti ini sebagai laki-laki eye candy. Penyajian tubuh laki-laki seperti ini tidak menutup kemungkinan bahwa pembaca Cosmopolitan tidak hanya perempuan, tapi juga laki-laki bahkan para homoseksual.

Dari delapan artikel terpilih, terdapat empat kategori maskulinitas yang sering muncul. Kategorisasi disimpulkan setelah melakukan pengamatan menyeluruh terhadap artikel tersebut. Ketiga kategori ini peneliti beri nama: "consumer bodies", "instrumental bodies", dan "objectified bodies”. Penamaan ketiga kategori tersebut dilakukan dengan pertimbangan utama menggambarkan representasi konsep maskulinitas secara umum.

\section{Consumer Bodies}

Asumsi bahwa perempuan merupakan pelanggan utama budaya konsumen, sudah ketinggalan zaman. Sementara itu, tidak mengejutkan jika 
dalam hubungan antara media populer dan konsep maskulinitas menghasilkan individu yang konsumtif. Kartajaya dalam Marketing in Venus mengungkap bahwa pasar potensial saat ini adalah Wo-Man. Yakni, bukan hanya perempuan, tapi juga laki-laki yang kewanita-wanitaan. Bukan dalam arti beralih orientasi seks, melainkan laki-laki yang mampu mengekspresikan perasaannya (Kartajaya, 2002: 19). Dengan merujuk pada Beckham sebagai ikon laki-laki yang bertubuh ideal dan menarik, membuat laki-laki ingin mengonsumsi produk yang sama, sekaligus menjadi pusat perhatian bagi yang melihat.

Seperti diungkapkan Benwell, maskulinitas yang berevolusi dalam majalah, erat kaitannya dengan cara kerja kapitalisme atas kebutuhan penyegaran pada pasar saat produknya sudah usang. Jika diasumsikan bahwa target pasar selama ini adalah perempuan, maka strategi yang diterapkan adalah strategi diferensiasi dengan produk baru untuk menyasar pasar yang baru. Walaupun esensi dari produk barangkali tidak berbeda secara signifikan dengan produk lama, tapi komunikasi pemasaran yang dibangun adalah produk baru.

Sasaran pasar yang berbeda, kemasan yang berbeda dan positioning yang berbeda. Dengan kata lain, penubuhan atas laki-laki sangat menguntungkan industri media dan pemodal. Sesuai pendapat Giddens, bahwa komodifikasi atas diri menekankan gaya pada diri yang bernilai (Giddens, 1991: 5). Dengan cara ini, keterwakilan laki-laki dalam Cosmopolitan Indonesia terkait dengan konsumsi produk tertentu. Representasi seperti ini sekaligus menjadi arena promosi, mengingat tingginya minat pengiklan dalam majalah Cosmopolitan Indonesia yang berorientasi pada konsumen kelas atas. Benar jika Foucault (2008) meletakkan tubuh sebagai pemegang kunci dalam filsafatnya. Tubuh berelasi kuat dengan kekuasaan yang membentuknya .

\section{Instrumental Bodies}

Kini, tubuh yang sempurna identik dengan prestasi, kontrol sosial dalam masyarakat, dan konstruksi media. Dengan cara ini, mudah dipahami bahwa kebutuhan kesempurnaan tubuh menjadi faktor pendorong industri media untuk meningkatkan pemasaran produk. Kesempurnaan diasumsikan sebagai kewajiban sosial saat ini. Memiliki tubuh yang sempurna, harus mampu menunjukkan komitmen dan konsistensi untuk mendisiplinkan diri. Majalah Cosmopolitan Indonesia mendesak pembacanya untuk menduplikasi diri seperti yang terlihat dalam majalah. Masalah penampilan fisik, rekayasa body building, kemudian menjamurnya pusatpusat olahraga, menjadi industri yang turut mengonstruksi laki-laki modern.

Laki-laki bertubuh kerempeng, lemah lembut dan loyo dianggap 
melempem dan tidak sepenuhnya menjadi laki-laki, sebab kemampuannya dalam menjaga perempuan akan diragukan. Dan lingkungan pun menerima standarisasi itu sebagai suatu yang wajar dan menyebutnya sebagai six packs. Sedangkan dalam tuntutan stereotipe tradisional, laki-laki sebaiknya harus kuat mengangkat beban apa saja, sehingga bisa terlihat keperkasaan dan kejantanannya. Sesuai dengan pemikiran Billman, "Men are now maintaining their masculine status through the repetition of building and maintaining this masculine body image" (dalam Journal Universitas, Vol. 2, Fall 2, 2006: 6).

Sistem kapitalisme memberikan kontribusi berupa pengaruh yang besar pada pembentukan body image. Kapitalisme adalah sang penentu standar tubuh ideal masa kini bagi laki-laki dan perempuan agar mereka memperbaiki penampilan secara berkesinambungan, hingga mencapai ukuran yang diidealkan. Meskipun itu sangat tidak dimungkinkan karena tak akan terjadi pencapaian titik kepuasan di masyarakat. Ini membenarkan apa yang dinyatakan Foucault bahwa tubuh selalu patuh. Perbaikan demi perbaikan dilakukan tanpa meminta ijin pada tubuh untuk disakiti dan dipoles. Semakin tinggi kemauan seseorang merenovasi tubuh, maka semakin tinggi pula peluang bagi investor untuk mengembangkan produk kejantanan dan kecantikan. Sedangkan hasrat perbaikan tubuh selalu diliputi kecemasan yang tak pernah selesai.

Praktik pendefinisian laki-laki maskulin seperti ini telah ada sebelumnya pada era 1880 hingga 1930. Eugene Sandow eksis di jamannya sekitar tahun 1889. Ia merupakan cikal bakal bentuk tubuh idaman binaraga seperti sekarang. Sandow memperoleh julukan "The World's Strongest Man" di Amerika. Kegemarannya memperlihatkan tubuh, sekaligus memperlihatkan kekuatannya di hadapan publik menjadikannya sebagai standar fisik hingga saat ini.

\section{Objectified Bodies}

Dalam hal ini, objektifikasi diri merupakan pementingan penampilan fisik daripada kompetensi fisik untuk menentukan kualitas tubuh. Tambahan properti seperti butter dan air menimbulkan efek mengkilap, sehingga lekuk tubuh dan otot terlihat jelas. Adapun Vogue dan Harper's Bazaar adalah majalah pertama yang menggunakan fotografi fashion dengan laki-laki sebagai objek. Fenomena foto laki-laki bertelanjang dada (male nude) atau perempuan yang menampakkan bagian tubuh secara terbuka, telah muncul sejak tahun 180o-an. Hanya saja, saat itu istilah yang digunakan adalah erotic photography. Ini diawali dengan penggambaran seseorang dalam bentuk lukisan. Dengan kemajuan teknologi, kemudian erotic photography 
berkembang dan lebih dikenal dengan nude photography. Sedangkan objek yang hanya menampakkan setengah bagian tubuhnya yang terbuka tanpa pakaian, maka disebut semi nude photography.

Dengan pemahaman ini, sangat sesuai jika ilustrasi Pin-Up menggambarkan laki-laki sedemikian rupa dan berorientasi pada "laki-laki baru”. Pada era 1980-an, di negara-negara maju bermunculan istilah "new man". Laki-laki ini memiliki sifat seperti perempuan yang mempunyai rasa perhatian dan kelembutan. Laki-laki jenis ini berasal dari kelas menengah, berpendidikan baik, dan intelek. Sementara itu pada 1990-an muncul lakilaki baru yang dikenal sebagai "new lad". Penunjukan maskulinitasnya melalui sepakbola, seks bebas, dan mementingkan leisure time sebagai masa bersenangsenang. Akhirnya laki-laki "metroseksual" menjadi jenis laki-laki baru di era 2000an yang hingga kini belum tergantikan.

Metroseksual menjadi potret beralihnya laki-laki menjadi objek tontonan. Akibatnya, konsep maskulinitas baru telah dibangun dan digambarkan secara sosial. Laki-laki jenis ini memiliki kesadaran terhadap penampilan fisik selayaknya perempuan dan jauh dari kesan maskulin. Tidak heran jika Simpson menjuluki laki-laki jenis ini sebagai metroseksual. Simpson menambahkan bahwa gejala yang disebut sebagai lakilaki baru ini hanyalah konstruksi dari pengiklan majalah glossy (istilah yang selalu digunakan Simpson untuk menunjuk majalah gaya hidup), yang menjual produk mahal dengan mengeksploitasi ketidakamanan laki-laki modern (Wibowo, 2006: 189-190).

\section{Penutup}

Proyek penubuhan merupakan publikasi visual terlaris dalam industri media. Terlebih, majalah merupakan agen sosialisasi yang sangat potensial. Pada satu sisi, penyajian ini menggambarkan fenomena maskulinitas yang selalu berubah dari masa ke masa. Sedangkan pada sisi lain, tubuh laki-laki berlaku sebagai tanda yang memiliki makna intertekstualitas oleh industri media global, sekaligus menarik perhatian lakilaki untuk menjadi konsumen baru.

Cosmopolitan Indonesia memang menghadirkan ragam ilustrasi visual yang berbeda pada tiap halaman dan edisi. Namun jika diamati menyeluruh, Cosmopolitan Indonesia menawarkan konsep tubuh laki-laki maskulin yang ideal secara homogen. Yang dimaksud homogen yakni, Cosmopolitan Indonesia merupakan majalah waralaba yang lisensinya dipegang oleh Hearst Magazines International di Amerika. Tentu saja tidak hanya Cosmopolitan Indonesia, majalah lain yang bernaung di bawahnya meliputi Esquire, Her World, Men's Health, Parent's Guide, Seventeen, dan Bazaar sudah dipastikan content-nya 
tidak berbeda jauh dengan perspektif Cosmopolitan Indonesia.

Penelitian semacam ini diharapkan dapat menjadi jendela untuk memahami konsep maskulinitas yang terus berubah pada kawasan tertentu. Ini bertujuan sebagai literasi media bagi masyarakat agar tidak terkena terpaan media yang mengkhawatirkan. Sebab media diperlakukan seperti barang dagangan, pengusaha hanya menerbitkan media yang laku dijual tanpa memperdulikan fungsi sosial media itu sendiri. Bahkan media tidak konsisten dalam memegang prinsip utama penerbitan media yakni komitmen untuk menyajikan keberagaman content.

\section{Daftar Pustaka}

Aliansi Jurnalis Independen. 2011. Menjelang Sinyal Merah: Laporan Tahunan Aliansi Jurnalis Independen. Jakarta: AJI.

Badinter, Elisabeth. 1995. XY: On Masculine Identity. New York: Columbia University Press.

Barthes, Roland. 2000. "The Photographic Message," A Roland Barthes Reader, ed. Susan Sontag. London: Vintage.

Beynon, John. 2002. Masculinities and Culture. Philadelphia: Open University Press.
Billman, Brett N. "The Enfleshment(s): Maintenance of Hegemonic Masculinity,” Journal Universitas, Vol. 2 (Fall, 2006), hal. 4.

Connell, R.W. 1995. Masculinities. Cambridge: Polity Press.

Foucault, Michel. 2008. Ingin Tahu Sejarah Seksualitas. Trans. Rahayu S. Hidayat. Jakarta: Yayasan Obor Indonesia.

Gauntlet, David. 2002. Media, Gender and Identity: An Introduction. London: Routledge.

Giddens, Anthony. 1991. Modernity and Self Identity: Self and Society in the Late Modern Age. Cambridge: Polity Press.

Johani, Mikael. "Beautiful Magazines," $a^{+}$, Agustus 2000.

Kartajaya, Hermawan. 2002. Marketing in Venus. Jakarta: Gramedia Pustaka Utama.

Muhadjir, Noeng. 2000. Metodologi Penelitian Kualitatif. Yogyakarta: Rake Sarasin.

Smiler, A.P. 2004. "Thirty Years After the Discovery of Gender: Psychological Concepts and Measures of Masculinity”. Journal of Sex Roles, Vol. 50, Nos. 1/2.

Wibowo, S. Kunto Adi. 2006. "Metrosexual," Resistensi Gaya Hidup: Teori dan Realitas, ed. Alfathri Adlin. Bandung: Jalasutra. 
Jurnal komunikasi, Volume 6, Nomor 2, April 2012 